\title{
PENERAPAN PSAK 73 PADA PERUSAHAAN PERTAMBANGAN YANG TERDAPAT DI BURSA EFEK INDONESIA PERIODE 2019
}

\author{
Salfadilla Rahmawati \\ salfadilla6@gmail.com, Politeknik Keuangan Negara STAN
}

\begin{abstract}
Abstact
PSAK 73 is a new accounting standard that adopts the old policy of IFRS 16. PSAK 73 regulates how an asset is recognized, measured, presented and disclosed in the financial statement. Lessees are only allowed to classify lease as finance lease except for short-term lease and lease where the underlying asset is of low value. This study aims to determine the impact of the application of PSAK 73 on lease on the company's financial performance with financial ratios. The sample of this study is two mining sector companies listed on the Indonesia Stock Exchange in 2019. This study uses a qualitative method with data collection techniques. In addition, the model method used is the constructive capitalization of lease developed by Imhoff, Lipe, and Wright (1991). The results of the study indicate that rental capitalization does not have a significant impact on the company's financial statement, with the current ratio and fixed ratio of the two companies decreasing. Net profit margin (NPM), return on assets (ROA), and return on equity (ROE) did not change. Debt to assets (DAR) and debt to equity (DER) have increased.
\end{abstract}

Keywords : PSAK 73, IFRS 16, finance lease, financial statement, financial ratios

\begin{abstract}
Abstrak
PSAK 73 merupakan standar akuntansi baru yang mengadopsi kebijakan lama IFRS 16. Dalam PSAK 73 mengatur mengenai bagaimana suatu aset diakui, diukur, disajikan dan diungkapkan di laporan keuangan. Penyewa hanya diperbolehkan mengklasifikasikan sewa sebagai sewa pembiayaan kecuali sewa jangka pendek dan sewa yang aset pendasarnya bernilai rendah. Penelitian ini bertujuan untuk mengetahui dampak dari penerapan PSAK 73 atas sewa terhadap kinerja keuangan perusahaan dengan rasio keuangan. Sampel dari penelitian ini adalah dua perusahaan sektor pertambangan yang terdapat di Bursa Efek Indonesia tahun 2019. Penelitian ini menggunakan metode kualitiatif dengan teknik pengumpulan data. Selain itu metode model yang digunakan adalah kapitalisasi konstruktif sewa yang dikembangkan oleh Imhoff, Lipe, dan Wright (1991). Hasil dari penelitian menunjukkan bahwa kapitalisasi sewa tidak berdampak secara signifikan terhadap laporan keuangan perusahaan dengan keterangan rasio lancar dan rasio tetap kedua perusahaan mengalami penurunan. Net profit margin (NPM), return on asset (ROA), dan return on equity (ROE) tidak mengalami perubahan. Debt to asset (DAR) dan debt to equity (DER) mengalami kenaikan.
\end{abstract}

Kata kunci : PSAK 73, IFRS 16, sewa pembiayaan, laporan keuangan, rasio keuangan

\section{PENDAHULUAN}

Aset tetap, aset berwujud yang dimiliki untuk digunakan dalam produksi atau penyediaan barang atau jasa untuk direntalkan kepada pihak lain, atau untuk tujuan administratif dan diharapkan untuk digunakan selama lebih dari satu periode. Hampir seluruh organisasi dan perusahaan memiliki aset tetap. Perolehan aset tetap mengharuskan perusahaan untuk mengeluarkan biaya perolehan atas aset tersebut. Menurut PSAK no 16, biaya perolehan berupa jumlah kas atau setara kas yang dibayarkan atau nilai wajar dari imbalan lain yang diserahkan untuk memperoleh suatu aset pada saat perolehan atau konstruksi. Perolehan aset tetap dapat dilakukan dengan cara membeli aset tetap tersebut (pengadaan aset tetap), membuat aset tersebut sendiri (pembangunan gedung), diperoleh dengan cara hibah (dalam negeri dan/atau luar negeri), pertukaran dengan aset lainnya dan dengan menyewa aset orang/perusahaan lain.

Menurut beberapa pandangan masyarakat ada beberapa pendapat yang menyebutkan bahwa untuk memiliki aset tetap maka kita tidak perlumembeli secara langsung dan dapat menyewa dari orang/perusahaan lainnya. Namun menurut beberapa masyarakat yang lain memiliki aset teap secara langsung dinilai jauh lebih baik daripada menyewa karena kita harus membayar pokok dan biaya bunganya. Sewa dinilai lebih menguntungkan perusahaan karena dengan menyewa aset dari pihak lain, maka perusahaan (yang menyewa) akan terhindar dari 


\section{JURNALKU}

Volume 1 No. 1, Maret 2021

kebutuhan dana besar serta biaya bunga yang tinggi. Sewa juga mengurangi risiko keuangan karena dapat mengoperkan barang yang disewakan kepada pihak yang memberikan sewa (lessor) apabila tidak diikuti dengan hak opsi. Perjanjian sewa juga lebih fleksibel karena lebih bebas dibandingkan dengan perjanjian utang lainnya dan sewa tidak menambah pos utang di neraca serta tidak mempengaruhi risiko leverage apabila sewa yang dipilih adalah sewa operasi.

Dengan adanya sewa guna usaha, pembiayaan perusahaan mengalami kenaikan aset tertanggal 19 Oktober sebesar 4,31\%. Kenaikan tersebut dinilai bahwa penggunaan metode sewa ini cukup baik untuk dilakukan perusahaan, untuk itu diperlukan kebijakan dan pedoman yang mengatur mengenai pengakuan, pengukuran, penyajian, dan pengungkapan atas sewa. Hal tersebut dilakukan dengan maksud agar dapat menyajikan informasi yang dibutuhkan bagi pembaca laporan keuangan. Kebijakan mengenai sewa tertuang dalam Pernyataan Standar Akuntansi Keuangan nomor 73 (PSAK 73) yang merupakan hasil adopsi dari Internationan Financing Reporting Standars 16 (IFRS 16) mengenai sewa. Sejak berlakunya Pedoman Standar Akuntansi Keuangan nomor 73 (PSAK 73) penerapan peraturan ini menggantikan beberapa standar yang sudah berlaku sebelumnya diantaranya PSAK 30 tentang sewa, Interpretasi Standar Akuntansi Keuangan (ISAK) 23 tentang sewa operasi, dan ISAK 25 tentang hak atas tanah.

Sejatinya peraturan tersebut sudah diterbitkan sejak 2017 dan baru berlaku efektif 1 Januari 2020. Latar belakang dari penerapan PSAK 73 adalah karena dengan model akuntansi sewa sebelumnya (PSAK 30) mensyaratkan penyewa dan pihak yang menyewakan untuk mengklasifikasikan sewa pada dua jenis yakni sewa pembiayaan dan sewa operasi serta melakukan pencatatan dengan cara yang berbeda pula. Model tersebut dinilai tidak dapat memenuhi kebutuhan pengguna laporan keuangan dikarenakan tidak memberikan penyajian yang tepat atas transaksi sewa. Oleh karena itu korporasi penyewa harus membukukan seluruh transaksi sewanya sebagai financial lease (sewa pembiayaan) kecuali untuk transaksi sewa yang sifatnya jangka pendek (sewa kurang dari 12 bulan) dan bernilai rendah.

Dalam praktik akuntansi di Indonesia, standar akuntansi tentang sewa diatur dalam PSAK 30 (IAI, 2014) yang mengadopsi IAS 17 (International Accounting Standards) dari IASB (International Accounting Standards Board). Sewa diklasifikasikan menjadi dua yakni sewa operasi dan pembiayaan yang memindahkan risiko dan manfaat aset ke penyewa. Perbedaan keduanya terletak pada transfer kepemilikan yang berdampak pada sewa operasi disajikan off balance sheet dan hanya mencatat sebagai beban sewa yang mempengaruhi laporan laba rugi. Kebijakan baru mengakibatkan perusahaan harus mencatat aset (sewa) dalam neraca. Hal tersebut perlu menjadi perhatian karena dapat mempengaruhi laporan keuangan perusahaan. Terdapat beberapa perusahaan pertambangan yang terdaftar di Bursa Efek Indonesia yang masih menggunakan pencatatan transaksi sewa dengan model lama, oleh sebab itu penelitian diarahkan terhadap dampak penerapan PSAK 73 pada perusahaan tersebut. Tujuan penelitian adalah untuk mengetahui dampak dari penerapan PSAK 73 atas sewa terhadap kinerja keuangan perusahaan pertambangan yang terdaftar di Bursa Efek Indonesia periode 2019, mengetahui pengaruh penerapan kebijakan tersebut pada perusahaan maupun pihak ketiga (investor), dan mengetahui rasio keuangan yang terpengaruh akibat dari penerapan implementasi.

\section{KAJIAN TEORI Aset Tetap}

Aset tetap merupakan aset yang digunakan untuk proses operasional perusahaan. Aset tetap cenderung memiliki nilai perolehan yang relatif tinggi dan transaksi yang dilakukan jarang. Pada perusahaan manufaktur, aset tetap menjadi hal yang vital agar perusahaan tersebut dapat memproduksi barang yang akan mereka jual dan menghasilkan pendapatan bagi 


\section{JURNALKU}

Volume 1 No. 1, Maret 2021

perusahaan. Dalam PSAK 16 (Revisi 2011) menyebutkan bahwa pengakuan aset tetap pada awalnya harus diukur sebesar harga perolehan. Komponen biaya perolehan aset tetap berupa : (1) bea impor dan pajak pembelian setelah dikurangi diskon dan potongan lainnya yang tidak boleh dikreditkan (2) biaya langsung yang digunakan untuk membawa aset tersebut ke lokasi sampai dengan aset siap untuk digunakan (3) biaya yang digunakan untuk pembongkaran dan pemindahan aset tetap yang diakibatkan karena penggunaan aset selama periode tertentu. Biaya perolehan aset tetap harus diakui sebagai aset jika (1) Entitas memperoleh manfaat ekonomi di masa depan. (2) Biaya perolehan dapat diukur secara andal.

Aset tetap dapat diperoleh dari berbagai macam cara yang mana cara tersebut mempengaruhi nilai perolehan aset tetap. Baridwan (2008) berpendapat terdapat beberapa cara untuk memperoleh aset tetap diantaranya pembelian tunai, pertukaran surat berharga, pertukaran asset tetap, asset yang diciptakan sendiri, dan hibah atau hadiah. Pernyataan Standar Akuntansi Keuangan Nomor 17 menyatakan pengertian penyusutan adalah alokasi aset yang dapat disusutkan selama masa manfaat yang sudah diestimasikan. Nilai yang disusutkan besarnya sama dengan nilai perolehan aset tetap dikurangkan dengan nilai sisa sehingga dihasilkan nilai aset pada akhir masa manfaatnya.

\section{Sewa Guna Usaha (Leasing)}

Secara bahasa leasing berasal dari Bahasa Inggris lease yang artinya menyewa. Kata tersebut pertama kali dikenal di Amerika Serikat pada tahun 1877 dan dikenal di Indonesia pada tahun 1974 (Martono, 2002). Dalam peraturan perundang-undangan, leasing dikenal dengan sebutan "sewa guna" yang didalamnya menyebutkan pernyataan sewa guna usaha adalah kegiatan pembiayaan dalam bentuk penyediaan barang modal (tanah atau mesin) selama jangka waktu dan pembayaran yang telah ditentukan (Kepmenkeu No. 1169/KMK.01/1991). Sewa adalah kesepakatan pada periode yang diberikan oleh lessor untuk menggunakan aset lessee lebih lanjutnya, pembayaran tersebut harus dilakukan lessee kepada lessor setelah diperolehnya hak atas penggunaan aset (Martani, 2018). Adanya perjajian sewa menimbulkan keharusan lessee untuk melakukan pembayaran dan di akhir masa sewa terdapat kemungkinan aset menjadi milik lessee atau dikembalikan kepada lessor. Sewa diklasifikasikan menjadi dua bagian yaitu sewa pembiayaan (finance lease/capital lease) dan sewa operasi (operating lease) (Diana \& Lilis, 2017).

\section{Laporan Keuangan}

Pengertian laporan keuangan menurut Pernyataan Standar Akuntansi Keuangan (PSAK) No. 1 merupakan bagian dari proses pelaporan keuangan. Laporan keuangan yang lengkap meliputi neraca, laporan laba rugi, laporan perubahan posisi keuangan, catatan atas laporan keuangan serta menyajikan mengenai informasi keuangan segmen industri dan geografis serta pengungkapan perubahan harga.

\section{Analisis Laporan Keuangan}

Laporan keuangan perusahaan menyajikan angka-angka yang memiliki sedikit makna sehingga perlu adanya analisis untuk menghubungkan makna-makna yang terkait dengan angka-angka tersebut. Analisis laporan keuangan dilakukan untuk mengetahui gambaran yang jelas dari sebuah laporan keuangan dan gambaran perusahaan pada suatu fenomena. Menurut Subramanyan (2014) analisis laporan keuangan merupakan bagian integral dan penting dalam bidang analisis bisnis yang lebih luas. Beliau juga berpendapat bahwa analisis laporan keuangan dapat dilakukan dengan berbagai cara, menurutnya ada lima alat penting yang digunakan antara lain (1) Analisis laporan keuangan komparatif; (2) Analisis laporan keuangan common size; (3) Analisis rasio; (4) Analisis arus kas dan; (5) Penilaian.

Analisis laporan keuangan common size digunakan untuk memahami susunan internal perusahaan. Dalam analisis ini dilakukan perbandingan antara pos yang satu dengan pos akun lain di tahun yang sama. Secara khusus dalam menganalisis neraca aset total dinyatakan $100 \%$ 


\section{JURNALKU}

Volume 1 No. 1, Maret 2021

dan dalam laba rugi penjualan ditetapkan $100 \%$. Kemudian dapat diketahui berapa persen kontribusi dari setiap pos akun (Subramanyam, 2014). Analisis rasio adalah yang paling sering digunakan dan sangat popular. Hal ini dikarenakan perhitungan rasio merupakan operasi aritmatika yang sederhana namun intepretasinya yang kompleks. Dengan intepretasi yang benar analisis suatu rasio dapat mengungkapkan hubungan dan basis perbandingan yang penting dalam kondisi dan tren yang sulit dideteksi dengan memeriksa masing-masing komponen penyusun rasio. Rasio harus merujuk pada hubungan yang penting secara ekonomi agar memiliki makna (Subramanyam, 2014).

Analisis arus kas adalah alat utama dalam mengevaluasi sumber dan penggunaan dana perusahaan. Analisis ini memberikan gambaran bagaimana perusahaan memperoleh pembiayaan dan untuk aktivitas apa saja sumber daya yang mereka miliki habis atau berkurang. Analisis ini adalah sebagai bagian dari analisis likuiditas (Subramanyam, 2014). Penilaian adalah analisis yang dilakukan untuk memperkirakan nilai intrinsik perusahaan dan sahamnya. Dasar penilaian adalah nilai sekarang atau present value. Teori present value mengacu pada konsep nilai waktu dari uang atau time value of money. Gagasan yang ada dalam teori ini adalah ada manfaat yang lebih besar untuk menerima sejumlah uang sekarang daripada jumlah yang identik nanti (Subramanyam, 2014).

\section{Analisis Rasio Keuangan}

Likuiditas mengacu kepada kemampuan suatu perusahaan untuk memenuhi kewajiban jangka pendeknnya (Subramanyam, 2014). Rasio likuiditas digunakan untuk menjawab pertanyaan mendasar mengenai kesehatan keuangan perusahaan, perusahaan dinilai likuid jika mampu membayar tagihannya tepat waktu (Tirman et al., 2014). Rasio likuiditas adalah rasio yang digunakan untuk menilai kesehatan keuangan perusahaan yang diukur melalui kemampuan perusahaan dalam melunasi kewajiban jangka pendeknya menggunakan aset lancar yang dimiliki.

Perusahaan akan mengakui aset sewaan yang sebelumnya tidak diakui dan mengakui kewajiban dari pembayaran minimum selama masa sewa oleh karena itu aset dan kewajiban akan meningkat dan rasio likuiditas juga akan mengalami perubahan. Rasio likuiditas terdiri dari current ratio (rasio lancar) dan quick ratio (rasio cepat). Current ratio (rasio lancar) adalah rasio yang membandingkan antara jumlah aset lancar perusahaan dengan jumlah kewajiban lancar yang dimiliki perusahaan. Rasio lancar yang semakin tinggi menunjukkan tingkat likuiditas perusahaan juga tinggi. Perusahaan mampu untuk melunasi kewajiban jangka pendeknnya dengan aset lancar yang dimilikinya. Rasio dibawah 1 dianggap lemah dan diatas 1,5 bernilai tinggi. Rasio ini juga harus dibandingkan dengan perusahaan lain yang sejenis.

Rasio likuiditas yang kedua adalah quick ratio (rasio cepat), analisis ini menggunakan aset lancar yang paling likuid atau aset yang mendekati uang tunai. Rasio ini mengukur kemampuan perusahaan dalam memenuhi kewajiban dengan aset yang paling likuid yang dimiliki olehnya. Menurut Subramanyam (2014) yang termasuk kategori aset likuid adalah uang tunai, investasi jangka pendek, dan piutang.

Rasio profitabilitas adalah rasio yang digunakan untuk mengukur kemampuan perusahaan memperoleh laba dari pendapatan yang berhubungan dengan penjualan, aset, dan ekuitas. Pada penerapan PSAK 73 perusahaan tidak lagi mengakui beban sewa tahunan tetapi menggantinya dengan beban penyusutan dan beban bunga. Dengan nilai beban yang sama tidak akan mengubah nilai laba rugi perusahaan akan tetapi dengan adanya penambahan aset sewaan akan mengubah tingkat pendapatan perusahaan terhadap asetnya. Rasio profitabilitas terdiri dari net profit margin/NPM (margin laba bersih), return on assets ratio/ROA (rasio pengembalian aset), dan return on equity ratio/ROE (rasio pengembalian ekuitas).

Rasio solvabilitas mencerminkan bagaimana perusahaan membiayai seluruh asetnya. Titman et al., (2014) menyebut rasio solvabilitas sama dengan rasio struktur modal. Pada saat 


\section{JURNALKU}

Volume 1 No. 1, Maret 2021

PSAK 73 diterapkan, maka aset perusahaan akan meningkat dan secara otomatis struktur modal perusahaan pada laporan keuangan akan berubah. Rasio solvabilitas terdiri dari debt to equity ratio/DER (rasio utang terhadap modal), debt to asset ratio/DAR (rasio utang terhadap aset aset), dan times interest earned/TIE (rasio cakupan bunga). Debt to equity ratio/DER (rasio utang terhadap modal) menunjukkan perbandingan kewajiban perusahaan dengan ekuitas yang dimiliki. Semakin tinggi rasio ini maka semakin tinggi penggunaan utang dari pada modal dalam membiayai aset perusahaan. Rasio utang terhadap modal ini akan meningkat seiring dengan peningkatan kewajiban perusahaan karena adanya kapitalisasi sewa operasi.

\section{METODE}

Metode pengumpulan data, data yang diperoleh kemudian diolah dengan menggunakan perbandingan dan rasio yang terkait dengan pembahasan. Data yang diolah diperoleh dari sumber-sumber yang berkaitan dengan objek karya tulis yang akan diselesaikan. Metode studi kepustakaan, jenis pengumpulan data yang meneliti berbagai macam dokumen terkait sebagai bahan analisis. Studi dokumen dilakukan untuk menghindari metode pengumpulan data yang lain seperti observasi dan wawancara guna menghindari kontak fisik dengan orang lain. Hal tersebut bertujuan untuk menjaga kesehatan diri sendiri dan orang lain dan juga mematuhi peraturan yang saat ini sedang diterapkan oleh pemerintah terkait pengurangan kontak fisik dengan orang lain serta menghindari kerumunan.

\section{HASIL DAN PEMBAHASAN}

\section{Gambaran Umum Perusahaan Pertambangan}

Terdapat banyak sekali perusahaan pertambangan yang ada di Indonesia, akan tetapi yang sudah terdaftar di Bursa Efek Indonesia kurang lebih hanya 49 perusahaan. Perusahaan petambangan dibagi menjadi tiga bagian sub sektor yaitu Sub Sektor Tambang Batu Bara, Sub Sektor Minyak \& Gas Bumi, Sub Sektor Penggalian Tanah/Batu, dan Sub Sektor Penambangan Logam \& Mineral. Terdapat dua perusahaan pertambangan sub sektor penambangan logam \& mineral yang menjadi perhatian penulis karena laporan keuangan 2019 kedua perusahaan tersebut dalam aspek leasing belum menggunakan peraturan atau kebijakan baru. Kedua perusahaan tersebut adalah PT Aneka Tambang Tbk (ANTAM) dan PT Timah Tbk (TINS). ANTAM terdaftar di BEI sejak tahun 1997 yang pada saat itu menawarkan 35\% sahamnya kepada publik. PT Timah Tbk (TINS) merupakan perusahaan yang berdiri sejak 2 Agustus 1976 yang pengelolaannya dibawah pemerintahan Belanda. TINS melakukan privatisasi dengan mencatatkan saham PT Tambang Tanah di BEI pada 19 Oktober 1995 sebesar 65\% dimiliki pemerintah dan 35\% disebar ke pasar.

PT Aneka Tambang Tbk (ANTAM)

Perusahaan yang mulai beroperasi secara komersial pada 5 Juli 1968 ini bergerak dalam bidang pertambangan simpanan alam, manufaktur, perdagangan, transportasi dan jasa terkait lainnya. ANTAM merupakan perusahaan yang terdiverifikasi dan terintegrasi secara vertikal yang orientasinya melakukan ekspor. Kegiatan ANTAM mencakup eksplorasi, penambangan, pengolahan dan pemasaran komoditas emas, nikel, perak, batubara dan barang tambang lainnya. Sebagai perusahaan dengan konsumen jangka panjang dari Eropa dan ASIA, ANTAM membentuk beberapa usaha patungan dengan mitra internasional untuk dapat menghasilkan keuntungan atas pemanfaatan cadangan bahan tambang. Perusahaan ini memiliki tujuan dasar untuk meningkatkan nilai perusahaan melalui penurunan biaya seiring dengan usaha bertumbuh guna menciptakan keuntungan berkelanjutan. Perusahaan melakukan peningkatan perolehan pendapatan, mendanai pertumbuhan masa depan, serta memberikan imbal hasil berupa dividend kepada para pemegang saham untuk mempertahankan kekuatan keuangan perusahaan. 


\section{JURNALKU}

Volume 1 No. 1, Maret 2021

Laporan keuangan yang tersaji pada ANTAM (lampiran 6) dalam bentuk rupiah yang mana menjadi mata uang fungsional perusahaan sehingga tidak memerlukan penyesuaian ulang dibandingkan jika laporan keuangan tersebut disusun dengan mata uang dolar Amerika Serikat (USD). Total Aset yang dimiliki ANTAM sebesar Rp30.194.907.730.000 dengan Rp7.665.239.260.000 yang merupakan aset lancar dan Rp22.529.668.470.000. Komponen penyusun aset berupa liabilitas sebesar Rp12.061.488.555.000 dan ekuitas sebesar Rp18.133.419.175.000. Laporan laba rugi ANTAM dapat dilihat di lampiran 7. Pada periode 2019, PT Aneka Tambang Tbk (ANTAM) mencatat adanya penurunan pendapatan dari periode sebelumnya sebesar 88\% atau sejumlah Rp1.442.150.560.000. Angka tersebut merupakan penurunan yang sangat signifikan. Penurunan yang sangat signifikan timbul akibat adanya wabah virus pada awal Maret 2019 sampai dengan sekarang.

PT Timah Tbk (TINS)

Timah (Persero) Tbk (TINS) didirikan pada 02 Agustus 1976 berdasarkan Akta No. 1 tanggal 2 Agustus 1976 secara komersial bergerak di bidang usaha pertambangan, industri, perdagangan, transportasi, dan jasa terkait usaha pertambangan. Perusaahan yang berpusat di Pangkalpinang Bangka Belitung ini telah terdaftar pada Bursa Efek Indonesia sejak 1995. Setelah terjadinya pandemi yang dialami di tahun 2019, proses pemulihan ekonomi akibat pandemi tersebut diprediksi akan berlangsung cepat. Lembaga keuangan dunia memprediksi bahwa pertumbuhan ekonomi global 2021 akan kembali berakselerasi. Produk timah yang dihasilkan TINS ini memiliki kualitas tinggi yang juga dilengkapi sertifikat produk (weight and analysis certicate) yang mengacu pada standar internasional, oleh karena itu produknya dapat diperdagangkan di pasar bursa logam dalam negeri atau luar negeri.

Sebagai bentuk inovasi dan perkembangan yang dilakukan oleh perusahaan, PT Timah Tbk bekerjasama dengan perusahaan lain untuk memproduksi produk non timah yang juga tentunya memenuhi standar kualitas internasional. Uniknya perusahaan yang dikenal bergelut dalam bidang pertambangan ini juga menjalankan kegiatan usaha di luar operasi penambangan seperti jasa teknik dan perbaikan kapal untuk melayani permintaan dari internal maupun eksternal perseroan, jasa bidang industri hilirisasi logam timah berupa produk tin chemical dan tin solder, jasa bidang agrobisnis yang mengembangkan usaha seperti peternakan, pertanian, dan jasa reklamasi lahan pertanian, kemudian jasa properti bergerak di sektor pembangunan atau pengelolaan tanah untuk pemukiman. Sebagai perusahaan pertambangan timah terbesar di Indonesia, PT Timah konsisten mengintensifkan kegiatan eksplorasi dalam rangka memperbaiki neraca cadangan timah, melanjutkan inovasi untuk menyempurnakan teknologi pengolahan bijih dalam rangka meningkatkan recovery, sehingga operasi penambangan lebih optimal dan efisien.

Laporan keuangan yang tersaji dalam TINS (lampiran 8) dalam bentuk rupiah yang mana menjadi salah satu mata uang fungsional PT Timah Tbk. Perusahaan tersebut memiliki beberapa mata uang fungsional, namun dalam pelaporannya mata uang asing selalu disajikan dalam bentuk rupiah disesuaikan dengan kurs yang dikeluarkan oleh Bank Indonesia. Total Aset yang dimiliki TINS sebesar Rp20.361.278.000.000 dengan Rp12.307.055.000.000 yang merupakan aset lancar dan sisanya termasuk aset tidak lancar sebesar Rp8.054.223.000.000. Komponen penyusun aset berupa liabilitas sebesar Rp15.102.873.000.000 dan ekuitas sebesar Rp5.258.405.000.000. Dalam laporan keuangan bagian laba rugi TINS (lampiran 9), PT Tambang Tbk mengalami kenaikan pendapatan usahanya sebesar $75,21 \%$ yang mana pada tahun 2018 pendapatan usaha TINS senilai Rp11.016.677.000.000 menjadi Rp19.302.627.000.000. Walaupun demikian, perusahaan timah tersebut mengalami kerugian yang cukup besar yakni senilai Rp608.776.000.000 yaitu rugi tahun berjalan dari operasi yang diberhentikan. Kerugian yang dialami oleh TINS tahun 2019 lebih sedikit dari yang dialami tahun lalu. Tahun sebelumnya TINS mengalami kerugian sebesar Rp792.633.000.000. 


\section{JURNALKU}

Volume 1 No. 1, Maret 2021

Rasio likuiditas akan berpengaruh terhadap penerapan PSAK 73 karena dengan peraturan tersebut kapitalisasi sewa operasi akan meningkatkan jumlah aset, utang jangka pendek, dan utang jangka panjangnya. Tabel rasio likuiditas sebelum diterapkannya PSAK 73 dalam tabel 1 menunjukkan rasio lancar (current ratio) dan rasio cepat (quick ratio) kedua perusahaan sebelum dilakukan kapitalisasi atas kebijakan PSAK 73. Rasio lancar Aneka Tambang (ANTAM) sebesar 144,81\% yang lebih besar daripada Perusahaan Timah (TINS) yakni $102,92 \%$ memperlihatkan bahwa aneka tambang mempunyai kemampuan yang lebih baik dalam membayar utang jangka pendek menggunakan aset lancarnya dibandingkan perusahaan timah. Rasio cepat ANTAM yakni 110,88\% juga hampir tiga kali lebih besar dari TINS yang hanya 48,55\% menunjukkan bahwa kemampuan ANTAM jauh lebih baik dalam membayar utang jangka pendek menggunakan aset paling lancar yang dimiliknya.

Tabel 1 Rasio Likuiditas sebelum Kapitalisasi Sewa

\begin{tabular}{|c|c|c|}
\hline Rasio Likuiditas & ANTAM & TINS \\
\hline Rasio Lancar (Current Ratio) & $144,81 \%$ & $102,92 \%$ \\
\hline Rasio Cepat (Quick Ratio) & $110,88 \%$ & $48,55 \%$ \\
\hline
\end{tabular}

Sumber : Diolah menggunakan Excel dari data Laporan Keuangan yang ada

Rasio profitabilitas ini dapat menjadi salah satu rasio yang dapat menunjukkan adanya pengaruh kapitalisasi sewa operasi akibat kebijakan baru mengenai sewa. Tabel 2 menunjukkan rasio profitabilitas kedua perusahaan sebelum diberlakukannya kebijakan PSAK 73. Besarnya net profit margin (margin laba bersih) dan return on asset (rasio pengembalian aset) aneka tambang lebih besar dari perusahaan timah menunjukkan bahwa efisiensi aneka tambang lebih besar dari perusahaan timah sehingga biaya operasi dapat ditekan dan aset yang dimiliki dapat dimanfaatkan dengan efisien.

Tabel 1 Rasio Profitabilitas sebelum Kapitalisasi Sewa

\begin{tabular}{|c|c|c|}
\hline Rasio Profitabilitas & ANTAM & TINS \\
\hline NPM & $0,59 \%$ & $5,20 \%$ \\
\hline ROA & $0,64 \%$ & $-2,99 \%$ \\
\hline ROE & $1,07 \%$ & $-11,58 \%$ \\
\hline
\end{tabular}

Sumber : Diolah menggunakan Excel dari data Laporan Keuangan yang ada

Analisis yang dilakukan yaitu dengan menghitung perbedaan rasio solvabilitas sebelum dan sesudah kapitalisasi sewa. Tabel 3 menunjukkan rasio solvabilitas kedua perusahaan sebelum kapitalisasi sewa sesuai dengan PSAK 73. Tingkat rasio utang terhadap ekuitas ANTAM memiliki nilai yang lebih baik dari TINS karena porsi utang terhap modal ANTAM semakin kecil dan sebaliknya. Rasio utang terhadap aset TINS memiliki nilai yang sangat baik dan lebih besar dari ANTAM, hal ini berarti TINS memiliki jaminan berupa aset dan uang yang diberikan oleh kreditor dalam jangka panjang semakin terjamin. TIE ANTAM menunjukkan nilai yang lebih baik dari TINS karena ANTAM lebih baik dalam membayar total beban bunga sampai 1,3 kali lipat daripada TINS.

Tabel 2 Rasio Solvabilitas sebelum Kapitalisasi Sewa

\begin{tabular}{|c|c|c|}
\hline Rasio Profitabilitas & ANTAM & TINS \\
\hline DER & $66,52 \%$ & $287,21 \%$ \\
\hline DAR & $39,95 \%$ & $74,17 \%$ \\
\hline TIE & 1,3 & $-0,92$ \\
\hline
\end{tabular}

Sumber : Diolah dengan Excel dari laporan keuangan yang ada

\section{Penerapan Standar Akuntansi atas Sewa pada setiap perusahaan}

Dalam keterangan yang ada pada laporan keuangan perusahaan, kedua perusahaan masih menggunakan standar akuntansi sewa lama yaitu PSAK 30 (revisi 2011) yang mana sewa pembiayaan akan diakui hanya jika sewa tersebut mengalihkan secara substansial seluruh risiko dan manfaat terkait dengan kepemilikan aset. Sewa nantinya juga akan diklasifikasikan sebagai 


\section{JURNALKU}

Volume 1 No. 1, Maret 2021

sewa operasi. Sewa operasi diakui oleh perusahaan sebagai beban dengan penyusutan menggunakan dasar garis lurus selama masa sewa, sedangkan sewa pembiayaan akan disusutkan berdasarkan metode unit produksi pada ANTAM. Penerapan PSAK baru ini akan mulai secara efektif digunakan pada periode baru yaitu awal bulan tahun 2020. Pada periode 2019 manajemen masih melakukan evaluasi yang mungkin terjadi dari penerapan PSAK baru tersebut.

Aneka Tambang (ANTAM) tidak menjelaskan secara rinci mengenai saldo sewa yang ada dalam laporan keuangan mereka. Mereka melakukan pengategorian sewa sebagai sewa operasi. Dalam laporan keuangan ANTAM 2019, sewa properti pertambangan dll masuk kategori sebagai beban, baik beban akrual, beban pokok penjualan, dan beban usaha. Dalam laporan keuangan 2020, aneka tambang melakukakan pengategorian terhadap sewa yang memiliki jangka waktu sewa kurang dari 12 bulan. Menurut keterangan yang terdapat pada Catatan atas Laporan Keuangan (CaLK) perusahaan, sewa yang sebagian besar resiko dan manfaat yang terkait dengan kepemilikan dipertahankan oleh lessor diklasifikasikan sebagai sewa operasi dan dibebankan pada laporan laba rugi konsolidasi perusahaan selama periode sewa.

\section{Pembahasan Hasil \\ Aktivitas Sewa Perusahaan}

Seluruh perusahaan telah menerapkan PSAK dalam Laporan Keuangan mereka masingmasing dan untuk sewa diberlakukan sesuai dengan PSAK 30. Kedua perusahaan yang penulis analisis mengungkapkan seluruh informasi kegiatan sewa perusahaan. Perusahaan Timah mencatat seluruh aktivitas sewa menyewa properti instasi dalam kategori aset tetap. Perusahaan aneka tambang masih mencatat sewa keseluruhan sebagai beban (sewa operasi). Nilai buku bersih aset sewa pembiayaan ANTAM sebesar Rp0 ini dari keseluruhan aset yang dimiliki oleh ANTAM. Sebagian besar nilai sewa untuk alat produksi tambang, sewa alat untuk pemrosesan penglogaman biji timah, sewa alat peleburan, sewa utilitas perusahaan, dan lainnya masuk dalam kategori sewa operasi. Aset sewa pembiayaan per 31 Desember 2019 untuk TINS dan ANTAM adalah Rp0. Hal tersebut menyebabkan penulis tidak dapat melakukan pengukuran terhadap besarnya komponen liabilitas sewa pembiayaan terhadap seluruh liabilitas keuangan kedua perusahaan. Sehubungan dengan PSAK 30 yang menyatakan bahwa perusahaan wajib melaporkan total pembayaran sewa operasi minimum masa depan pada akhir periode pelaporan, TINS dan ANTAM menyajikan pembayaran sewa operasi kedalam beban pada laba rugi konsolidasian selama periode sewa.

\section{Penyajian Kembali Laporan Keuangan}

Penyajian kembali laporan keuangan dilakukan dengan mengkapitalisasi nilai yang terpengaruh pada penerapan PSAK 73 mengenai sewa. Seluruh sewa operasi yang dilaporkan akan dikapitalisasi dan sewa operasi yang nilainya rendah dan memiliki jangka waktu kurang dari 1 tahun akan digolongkan sebagai sewa operasi lainnya. Aspek lain dalam laporan keuangan dianggap tetap atau konstan.

Asumsi yang akan digunakan

Penyajian kembali laporan keuangan memerlukan banyak data antara lain jumlah pembayaran masa depan sewa operasi, tingkat bunga yang digunakan, nilai saat ini dari pembayaran sewa, dan kebijakan mengenai penyusutan aset. Dikarenakan informasi yang tertuang dalam laporan keuangan yang disediakan untuk umum kurang lengkap, maka untuk melakukan penyajian kembali harus ada asumsi yang dibuat.

Asumsi pertama yang harus muncul adalah mengenai bunga sewa. Perusahaan melaporkan sewa operasinya dalam laporan laba rugi konsolidasi, maka tidak terdapat keterangan tingkat bunga yang ditetapkan. Suku bunga pinjaman inkremental rata-rata tertimbang adalah 7,24\%-9,29\% untuk kedua perusahaan (perusahaan timah tidak menyajikan 


\section{JURNALKU}

Volume 1 No. 1, Maret 2021

mengenai bunga implisit ataupun bunga pinjaman inkremental) maka dari itu penulis berasumsi rata-rata tingkat bunga yang ditetapkan untuk ANTAM dan TINS adalah 8,3\%.

Asumsi selanjutnya adalah dalam melakukan klasifikasi atas libilitas sewa yang jatuh tempo dalam 1 tahun dan lebih dari 1 tahun dilakukan dengan melakukan perbandingan liabilitas sewa di tahun 2020 atas liabilitas sewa jatuh tempo dalam 1 tahun dan lebih dari satu tahun. Perbandingan tersebut antara lain untuk liabilitas sewa jatuh tempo dalam 1 tahun sebesar 45,4\% dari jumlah keseluruhan liabilitas sewa dan sisanya yakni 54,6\% masuk pada liabilitas sewa jatuh tempo lebih dari 1 tahun.

ANTAM

Komitmen dari sewa operasi disajikan dalam laba rugi konsolidasi perusahaan dan dibebankan setiap periode, hal tersebut mengakibatkan tidak adanya pembayaran sewa operasi di masa yang akan datang. Dalam kapitalisasi sewa, perusahaan telah menyebutkan nilai yang akan dijadikan sebagai aset (dalam aset tetap) secara langsung di CaLK dan sebagai kewajiban baik jangka pendek maupun jangka panjang. Aset sewaan atau disebut dengan aset guna usaha yang diklasifikasikan dengan nama akun baru yaitu aset hak guna. Dalam keterangannya aset perusahaan akan meningkat sebesar Rp130.381.324.000 dan kewajiban perusahaan akan naik senilai Rp128.608.040.000. Kewajiban jangka pendek sebesar Rp58.388.050.160 dan kewajiban jangka panjang sebesar Rp70.219.989.840. Kemudian beban sewa operasi pada periode berjalan harus digantikan dengan beban penyusutan dan beban keuangan. Total beban sewa operasi perusahaan Aneka Tambang senilai Rp452.204.541.000. Nilai tersebut 8,3\% nya dialokasikan ke beban keuangan mendapat Rp37.532.976.903 dan sisanya dialokasikan pada beban depresiasi yakni Rp414.671.564.097. Tabel 4 menunjukkan perbandingan laporan keuangan perusahaan sebelum dan sesudah adanya kapitalisasi sewa operasi.

Tabel 3 Perbandingan Laporan Keuangan ANTAM

\begin{tabular}{|l|l|l|l|c|}
\hline & \multicolumn{1}{|c|}{ Dilaporkan } & \multicolumn{1}{c|}{ Disajikan Kembali } & \multicolumn{2}{c|}{ Selisih } \\
\hline $\begin{array}{l}\text { Aset Tetap } \\
\text { Kewajiban Jangka }\end{array}$ & 18.865 .691 .270 .000 & 18.996 .072 .594 .000 & 130.381 .324 .000 & $0,69 \%$ \\
\hline $\begin{array}{l}\text { Kendek } \\
\text { Panjang }\end{array}$ & - & 58.388 .050 .160 & 58.388 .050 .160 & $\infty$ \\
\hline $\begin{array}{l}\text { Beban Jangka } \\
\text { Beban Penyusutan }\end{array}$ & - & 70.219 .989 .840 & 70.219 .989 .840 & $\infty$ \\
\hline Beban Keuangan & 1.054 .093 .936 .000 & 1.468 .765 .500 .097 & 414.671 .564 .097 & $39,34 \%$ \\
\hline
\end{tabular}

Sumber : Diolah dengan Excel dari laporan keuangan perusahaan

Laporan keuangan perusahaan disajikan kembali secara lengkap pada lampiran 1 sampai dengan lampiran 3. Efek yang ditimbulkan karena adanya kapitalisasi sewa operasi adalah kenaikan pada aset tetap dan kewajiban perusahaan. Aset tetap ANTAM mengalami peningkatan sebesar $0,69 \%$ yang mengakibatkan kenaikan pada keseluruhan aset sebesar $0,43 \%$. Saldo ekuitas tidak mengalami perubahan sama sekali. Beban penyusutan dan beban keuangan juga mengalami perubahan. Beban penyusutan mengalami kenaikan sebesar 39,34\% dan beban keuangan meningkat sebesar $16,08 \%$. Meskipun tidak adanya perubahan pada jumlah laba (rugi) bersih perusahaan, beberapa rasio keuangan tetap berubah. $\underline{\text { TINS }}$

Berbeda dengan ANTAM, TINS melaporkan sewanya dalam akun properti investasi yang masuk kedalam kategori aset tetap perusahaan. Oleh karena itu penulis tidak dapat 


\section{JURNALKU}

Volume 1 No. 1, Maret 2021

memberikan penyajian ulang terhadap laporan laba rugi perusahaan. Di sisi lain TINS memberikan ulasan mengenai dampak diterapkannya PSAK 73 yang menyebabkan adanya kenaikan aset tetap dan liabilitas perusahaan. Terdapat penambahan aset tetap kategori aset hak guna yang seharusnya tercatat di laporan keuangan perusahaan pada periode 2019 sebesar Rp30.315.000.000 dan peningkatan pada kewajiban jangka pendek dan jangka panjang sebesar masing-masing Rp26.082.000.000 dan Rp12.168.000.000. Kewajiban jangka panjang atas sewa pada periode sebelumnya tidak disajikan, namun dalam periode 2019 kewajiban jangka panjang atas sewa sebesar tercatat sebesar Rp12.168.000.000. Tabel 5 menunjukkan perubahan saldo akun yang terpengaruh karena adanya kapitalisasi sewa operasi.

Laporan keuangan perusahaan TINS terlampir pada lampiran 4 sampai dengan lampiran 5. Efek yang ditimbulkan dari penerapan kebijakan sewa baru ini terhadap neraca yaitu adanya peningkatan pada aset tetap sebesar $0,84 \%$ yang menyebabkan jumlah keseluruhan aset meningkat sebesar $0,15 \%$. Jumlah kewajiban jangka panjang juga mengalami kenaikan, yang sebelumnya tidak ada saldo terkait aktivitas sewa pada liabilitas jangka panjang karena adanya kebijakan baru maka terjadi kenaikan yang cukup besar namun tidak signifikan. Kewajiban jangka pendek mengalami peningkatan sebesar $0,22 \%$ akibat adanya kebijakan baru ini. Sementara itu sisi ekuitas perusahaan tidak mengalami perubahan sama sekali.

Tabel 4 Perbandingan Laporan Keuangan TINS

\begin{tabular}{|l|c|c|c|c|}
\hline & Dilaporkan & $\begin{array}{c}\text { Disajikan } \\
\text { Kembali }\end{array}$ & \multicolumn{2}{|c|}{ Selisih } \\
\hline Aset Tetap & 3.601 .375 .000 .000 & 3.631 .690 .000 .000 & 30.315 .000 .000 & $0,84 \%$ \\
\hline $\begin{array}{l}\text { Kewajiban Jangka } \\
\text { Pendek }\end{array}$ & 129.001 .000 .000 & 155.083 .000 .000 & 26.082 .000 .000 & $0,22 \%$ \\
\hline $\begin{array}{l}\text { Kewajiban Jangka } \\
\text { Panjang }\end{array}$ & - & 12.168 .000 .000 & 12.168 .000 .000 & $\infty$ \\
\hline
\end{tabular}

Sumber : Diolah dengan Excel dari laporan keuangan perusahaan

\section{Pengaruh Terhadap Rasio Keuangan}

Setelah ada penyajian kembali laporan keuangan perusahaan yang penulis lakukan, selanjutnya penulis akan menguji dampak yang timbul akibat perubahan saldo laporan keuangan sebelumnya dengan menghitung rasio keuangan, yaitu rasio likuiditas, rasio profitabilitas, dan rasio solvabilitas. Disajikan tabel yang berisi mengenai perbandingan rasio sebelum dan setelah dilakukan kapitalisasi pada masing-masing perusahaan.

$\underline{\text { Rasio Likuiditas }}$

Kedua perusahaan perusahaan mengalami penurunan pada rasio likuiditasnya. Pada perusahaan ANTAM, rasio lancar (current ratio) mengalami penurunan sebasar $1,58 \%$ dan rasio cepat (quick ratio) mengalami penurunan sebesar 1,21\%.

Tabel 5 Perbandingan Rasio Likuiditas ANTAM

\begin{tabular}{|c|c|c|c|}
\hline ANTAM & Sebelum Kapitalisasi & Setelah Kapitalisasi & Perbedaan \\
\hline Rasio Lancar & $144,81 \%$ & $143,23 \%$ & $-1,58 \%$ \\
\hline Rasio Cepat & $110,88 \%$ & $109,67 \%$ & $-1,21 \%$ \\
\hline \multicolumn{4}{|c|}{$\begin{array}{c}\text { Sumber : Diolah dengan Excel dari laporan keuangan perusahaan } \\
\text { Tabel } 6 \text { Perbandingan Rasio Likuiditas TINS }\end{array}$} \\
\hline TINS & Sebelum Kapitalisasi & \begin{tabular}{c|} 
Setelah \\
Kapitalisasi \\
\end{tabular} & Perbedaan \\
\hline Rasio Lancar & $102,92 \%$ & $102,69 \%$ & $-0,22 \%$ \\
\hline Rasio Cepat & $48,55 \%$ & $48,44 \%$ & $-0,11 \%$ \\
\hline
\end{tabular}

Sumber : Diolah dengan Excel dari laporan keuangan perusahaan

Sebelum dilakukan penyajian kembali laporan keuangan, ANTAM memiliki rasio lancar dan rasio cepat diatas angka 1. Angka ini berarti kondisi keuangan perusahaan sangat 


\section{JURNALKU}

Volume 1 No. 1, Maret 2021

baik, pasalnya ANTAM tidak mengalami kesulitan dalam membayar kewajiban jangka pendeknya menggunakan aset lancar yang dimilikinya. Setelah dilakukan penyajian ulang, adanya kebijakan baru mengenai sewa (PSAK 73) tidak mempengaruhi besanya rasio lancar dan rasio cepat perusahaan secara signifikan, angka rasio masih di atas 1 dan kemampuan perusahaan dalam melunasi kewajiban jangka pendeknya dengan aset lancar masih sangat baik. Berbeda halnya dengan perusahaan TINS, sebelum dilakukan penyajian kembali, hanya rasio cepat TINS masih jauh dari angka 1. Angka ini menunjukkan bahwa kondisi keuangan perusahaan sedang buruk, perusahaan mengalami kesulitan dalam melunasi kewajiban jangka pendeknya dengan aset lancar yang paling likuid yang mereka miliki. Kapitalisasi sewa operasi menyebabkan penurunan rasio likuiditas kedua perusahaan, namun penurunan tersebut masih wajar dan tidak menunjukkan presentase yang signifikan yang mempengaruhi pengambilan keputusan perusahaan dan pihak eksternal.

$\underline{\text { Rasio Profitabilitas }}$

Tabel 7 Perbandingan Rasio Profitabilitas ANTAM

\begin{tabular}{|c|c|c|c|}
\hline ANTAM & $\begin{array}{c}\text { Sebelum } \\
\text { Kapitalisasi }\end{array}$ & $\begin{array}{c}\text { Setelah } \\
\text { Kapitalisasi }\end{array}$ & Perbedaan \\
\hline NPM & $0,59 \%$ & $0,59 \%$ & $0,00 \%$ \\
\hline ROA & $0,64 \%$ & $0,64 \%$ & $0,00 \%$ \\
\hline ROE & $1,07 \%$ & $1,07 \%$ & $0,00 \%$ \\
\hline
\end{tabular}

Sumber : Diolah dengan Excel dari laporan keuangan perusahaan

Tabel 8 Perbandingan Rasio Profitabilitas TINS

\begin{tabular}{|c|c|c|c|}
\hline TINS & $\begin{array}{c}\text { Sebelum } \\
\text { Kapitalisasi }\end{array}$ & $\begin{array}{c}\text { Setelah } \\
\text { Kapitalisasi }\end{array}$ & Perbedaan \\
\hline NPM & $-5,51 \%$ & $-5,51 \%$ & $0,00 \%$ \\
\hline ROA & $-2,99 \%$ & $-2,99 \%$ & $0,00 \%$ \\
\hline ROE & $-11,58 \%$ & $-11,58 \%$ & $0,00 \%$ \\
\hline
\end{tabular}

Sumber : Diolah dengan Excel dari laporan keuangan perusahaan

Tabel 8 menunjukkan perbandingan rasio profitabilitas yang terjadi pada laporan keuangan ANTAM sebelum dan setelah dilakukannya penyajian ulang. Pada rasio tersebut yang mengalami perubahan hanya pada pengembalian atas aset (return on asset/ROA). Perubahan tersebut hanya terjadi pada rasio pengembalian dan nilainya sangat kecil sehingga terlihat seperti tidak ada perbedaan, hal tersebut terjadi karena kapitalisasi sewa operasi hanya menambah aset sewa dan kewajiban sewa tersebut, sehingga untuk bagian ekuitas tidak terjadi perubahan. Hal serupa juga terjadi pada TINS yang mana rasio profitabilitas tidak mengalami perubahan karena kapitalisasi sewa operasi tidak mempengaruhi ekuitas perusahaan.

$\underline{\text { Rasio Solvabilitas }}$

Rasio solvabilitas atau rasio struktur modal seperti yang ditunjukkan tabel 10 dan tabel 11 sebagian besar rasio terkait rasio solvabilitas mengalami kenaikan dengan jumlah yang tidak signifikan. Rasio utang terhadap ekuitas (DER) ANTAM sebelum dan sesudah dilakukan kapitalisasi hanya meningkat sebesar $0,32 \%$ dan kenaikan ini tidak bersifat signifikan. Sebelum kapitalisasi, sewa DER berada pada nilai $66,52 \%$ artinya 0,7 kali total modal ANTAM, begitu pula dengan TINS yang memiliki utang lebih dari 2 kali total modalnya. DER yang sifatnya ideal adalah DER yang memiliki nilai di bawah 1, tapi bukan berarti DER diatas 1 menandakan perusahaan mengalami kesulitan dalam membayar utangnya, harus ditelusuri terlebih dahulu utang perusahaan terbentuk dari apa, apakah utang kepada pihak ketiga atau utang pendapatan diterima di muka ataupun utang lainnya. Jika dilihat dari laporan keuangan perusahaan keduanya, utang yang mereka miliki sebagian besar adalah utang bank, utang pinjaman, dan utang lainnya. Oleh karena itu perusahaan memiliki kewajiban untuk membayar pokok dan bunga utang. Kondisi yang dialami ANTAM dikategorikan sehat, karena rasio DER kurang 


\section{JURNALKU}

Volume 1 No. 1, Maret 2021

dari 1 dan utang-utang yang dimiliki tidak akan mengganggu likuiditas perusahaan dan menekan labanya. Berbeda halnya dengan TINS, kondisi rasio DER TINS dikategorikan kurang sehat karena utang-utangnya akan mengganggu likuiditas dan menekan laba perusahaan. Kapitalisasi sewa operasi kedua perusahaan mengalami kenaikan namun tidak cukup tinggi. Akibat yang ditimbulkan adalah memperburuk rasio utang terhadap ekuitas mereka namun perubahannya sangat kecil.

Tabel 9 Perbandingan Rasio Solvabilitas ANTAM

\begin{tabular}{|c|c|c|c|}
\hline ANTAM & $\begin{array}{c}\text { Sebelum } \\
\text { Kapitalisasi }\end{array}$ & $\begin{array}{c}\text { Setelah } \\
\text { Kapitalisasi }\end{array}$ & Perbedaan \\
\hline DER & $66,52 \%$ & $66,84 \%$ & $0,32 \%$ \\
\hline DAR & $39,95 \%$ & $39,97 \%$ & $0,02 \%$ \\
\hline TIE & 1,30 & 1,30 & - \\
\hline
\end{tabular}

Sumber : Diolah dengan Excel dari laporan keuangan perusahaan Tabel 10 Perbandingan Rasio Solvabilitas TINS

\begin{tabular}{|c|c|c|c|}
\hline TINS & $\begin{array}{c}\text { Sebelum } \\
\text { Kapitalisasi }\end{array}$ & $\begin{array}{c}\text { Setelah } \\
\text { Kapitalisasi }\end{array}$ & Perbedaan \\
\hline DER & $287,21 \%$ & $287,94 \%$ & $0,73 \%$ \\
\hline DAR & $74,17 \%$ & $74,25 \%$ & $0,08 \%$ \\
\hline TIE & $-94,42$ & $-94,42$ & - \\
\hline
\end{tabular}

Sumber : Diolah dengan Excel dari laporan keuangan perusahaan

Sebelum adanya kapitalisasi, rasio terhadap aset (DAR) TINS memiliki nilai rasio yang cukup tinggi yakni hampir $100 \%$. Hal ini menandakan bahwa sebanyak 74,16\% aset TINS dibiayai oleh utang sedangkan rasio terhadap aset (DAR) ANTAM sebesar 39,95\% artinya sebanyak 39,95\% aset ANTAM dibiayai oleh utang. Hampir seluruh aset TINS dibiayai oleh utang. Setelah adanya kapitalisasi sewa, rasio kedua perusahaan mengalami kenaikan yang sangat kecil dan tidak mempengaruhi aspek apapun. Rasio cakupan bunga (TIE), rasio yang mengukur kemampuan perusahaan dalam membayar bunga masa depannya. Rasio cakupan bunga kedua perusahaan tidak mengalami kenaikan ataupun penurunan karena perusahaan tidak menyajikan pembayaran untuk sewa operasi dalam jangka waktu kedepannya, oleh karena itu penulis tidak mampu melakukan pengukuran kembali. Secara konsep kapitalisasi sewa operasi menyebabkan beban bunga perusahaan akan meningkat karena harus mengakui bunga atas pembayaran sewa. Perusahaan menyajikan beban sewa operasi pada laporan laba rugi perusahaan setiap periodenya. Oleh karena itu penulis tidak dapat mengkalkulasi hal tersebut.

\section{PENUTUP}

Dampak dari penerapan PSAK 73 adalah dengan pengkapitalisasian semua sewa operasi perusahaan menggunakan metode penyajian kembali laporan keuangan. Kemudian dilakukan perbandingan rasio keuangan antara laporan keuangan perusahaan dan laporan keuangan perusahaan yang disajikan kembali. Analisis rasio dilakukan dengan menggunakan rumus aritmatik yang sederhana serta bersifat umum dan popular sehingga akan dengan mudah dipahami oleh pembaca. Rasio yang terlibat dalam analisis adalah rasio likuiditas, profitabilitas, dan solvabilitas. Sebelum dilakukan penyajian ulang laporan keuangan perusahaan, ANTAM memiliki rasio likuiditas yang sangat sehat yang mana rasio lancarnya lebih dari 100\% begitupun dengan rasio cepatnya. Sedangkan TINS memiliki rasio lancar yang juga sangat bagus namun rasio cepat TINS kurang dari 1 yang berarti bahwa TINS kurang mampu melunasi kewajibannya menggunakan aset lancar paling likuid yang mereka miliki.

Untuk rasio profitabilitas, sebelum dilakukan penyajian ulang laporan keuangan, hampir seluruh rasio yang dimiliki oleh TINS benilai negatif karena TINS mengalami kerugian pada tahun 2019, berbeda halnya dengan ANTAM. Margin laba bersih ANTAM menunjukkan 


\section{JURNALKU}

Volume 1 No. 1, Maret 2021

bahwa ANTAM lebih efisien dalam menjalankan operasinya dibandingkan dengan TINS karena nilai selisihnya yang cukup jauh yakni masing-masing 0,59\% dan $-5,51 \%$. Rasio pengembalian atas aset ANTAM juga memiliki tingkat produktifitas dan efisiensi yang tinggi dibandingkan dengan TINS.

Rasio solvabilitas atau struktur perusahaan sebelum dilakukan penyajian kembali menunjukkan bahwa utang perusahann lebih besar dari modalnya. Rasio utang terhadap ekuitas ANTAM menunjukkan $66,52 \%$ yang berarti jumlah utang perusahaan mencapai 0,7 kali dari modal perusahaan dan TINS mencapai $287,21 \%$ yang berarti jumlah utang perusahaan mencapai 2 kali dari modal perusahaan. Rasio utang terhadap aset untuk TINS hampir menyentuh angka 100\% yang menunjukkan bahwa hampir semua aset perusahaan dibiayai menggunakan utang. ANTAM hanya sebagian kecil dari asetnya yang dibiayai menggunakan utang. Rasio cakupan bunga, TINS tidak memiliki rasio yang cukup relevan yang dapat diterapkan karena TINS mengalami kerugian yang artinya tidak memiliki laba untuk membayar beban bunga masa depan. Sedangkan ANTAM menghasilkan angka 1,3 yang artinya perusahaan menghasilkan pendapatan yang cukup untuk membayar total beban bunga 1,3 kali lipat dengan kata lain pendapatan perusahaan 1,3 kali lebih tinggi dari biaya bunga pada periode 2019.

Akibat adanya kapitalisasi sewa operasi, beberapa item dalam neraca dan dalam laporan laba rugi kedua perusahaan mengalami perubahan. Aset tetap ANTAM dan TINS mengalami kenaikan yang kecil yaitu masing-masing sebesar $0,69 \%$ dan $0,84 \%$. Kewajiban jangka pendek kedua perusahaan juga mengalami kenaikan yang kecil yaitu masing-masing sebesar $1,10 \%$ dan $0,22 \%$. Berbeda hal nya dengan kewajiban jangka panjang dimana kewajiban jangka panjang ANTAM tidak mengalami kenaikan maupun penurunan, namun kewajiban jangka panjang TINS mengalami kenaikan sebesar 0,39\%. Beban operasional kedua perusahaan juga mengalami perubahan karena adanya penghapusan beban sewa operasi tahun berjalan dan pengalokasian kepada beban penyusutan dan beban keuangan. Beban operasional ANTAM menurun sebesar Rp452.204.541.000 atau senilai 1,47\% dan mengalami kenaikan pada beban penyusutan sebesar 39,34\% serta beban keuangan sebesar 16,08\%. Dalam laporan laba rugi TINS , beban operasional tidak mengalami perubahan karena TINS telah mengkapitaliasi sewa operasi nya menjadi aset tetap.

Dampak pada rasio likuiditas setelah adanya kapitalisasi tidak terlalu besar dan semua pada rentan kurang dari 5\%. Rasio lancar dan rasio cepat ANTAM hanya menurun sebesar $1,58 \%$ dan $1,21 \%$ sedangkan TINS hanya menurun sebesar $0,22 \%$ dan $0,11 \%$. Maka dapat disimpulkan bahwa PSAK 73 dapat membawa dampak buruk pada rasio likuiditas dengan nilai tergantung pada jumlah sewa operasi perusahaan. Hal tersebut dikarenakan perusahaan harus mengakui kewajiban jangka pendek atas pembayaran sewa yang sebelumnya tidak diakui pada laporan keuangan.

Rasio profitabilitas kedua perusahaan tidak terlalu berdampak dengan adanya kapitalisasi sewa operasi karena ekuitas tidak mengalami perubahan yang diakibatkan kapitalisasi sewa operasi. Pada laporan laba rugi pun tidak mempengaruhi laba bersih perusahaan, dalam hal ini hanya mempengaruhi atau mengubah item beban perusahaan.

Rasio solvabilitas atau rasio struktur modal tidak memiliki dampak yang signifikan setelah dilakukan kapitalisasi sewa operasi. Rasio utang pada ekuitas kedua perusahaan menjadi lebih buruk. Pada perusahaan ANTAM meningkat sebesar 0,32\% dan pada perusahaan TINS meningkat sebesar $0,73 \%$ artinya total utang yang dimiliki perusahaan meningkat $0,32 \%$ dan $0,73 \%$ dari modalnya. Rasio utang terhadap aset ANTAM meningkat sebesar 0,02\% dan TINS sebesar $0,08 \%$. Rasio utang pada ekuitas mengalami kenaikan yang sangat kecil sehingga tidak memberikan dampak yang berarti pada laporan keuangan perusahaan setelah disajikan ulang. Rasio cakupan bunga yang menggambarkan kemampuan perusahaan dalam membayar bunga 


\section{JURNALKU}

Volume 1 No. 1, Maret 2021

masa depan menggunakan laba yang diperoleh. Karena hanya ANTAM yang menghasilkan laba, kapitalisasi sewa operasi membuat ANTAM harus mengakui beban bunga atas pembayaran sewa namun ANTAM mengakui seluruh beban bunga tersebut dalam lapoan laba rugi yang dilakukan setiap periode akuntansi sehingga tidak menimbulkan efek pada laporan keuangan perusahaan bagian laba rugi.

Dari ketiga rasio yang sudah dilakukan analisis, dapat ditarik kesimpulan bahwa kapitalisasi sewa operasi yang terjadi ketika PSAK 73 diterapkan menyebabkan laporan keuangan perusahaan pertambangan yang terdaftar dalam Bursa Efek Indonesia menjadi lebih buruk, namun secara keseluruhan tingkat penurunan yang terjadi tidak signifikan. Utang perusahaan menjadi meningkat, walaupun aset perusahaan juga mengalami peningkatan.

\section{DAFTAR PUSTAKA}

Ahalik. (2019). Perbandingan Standar Akuntansi Sewa PSAK 30 Sebelum dan Sesudah Adopsi IFRS serta PSAK 73. Jurnal Aset (Akuntansi Riset), 11 (1): 165-173.

Antam. (n.d.). Profil Perusahaan Tentang Antam. https://www.antam.com/id/about.

Ariestiyansi, Dwi. (2012). Analisis Implikasi Kapitalisasi Leasing Terhadap Rasio Laporan Keuangan Perusahaan Manufaktur yang Terdaftar di Bursa Efek Indonesia Tahun 20072010 [Skripsi]. Universitas Indonesia.

Baridwan, Zaki. (2008). Akuntansi Intermediate. Edisi ke-8. BPPE.

Britama.com. (2012). Sejarah dan Profil Singkat TINS (Timah (Persero) Tbk). http://britama.com/index.php/2012/06/sejarah-dan-profil-singkat-tins/.

Bungfei. (2019). Pengertian Leasing Menurut Para Ahli. https://www.bungfei.com/2019/03/pengertian-leasing-menurut-para-ahli.html.

Bursa Efek Indonesia. (2010). Laporan Keuangan dan Tahunan. IDX. https://www.idx.co.id/. Ekonomi, guru. (1 November 2020). Pengertian Aktiva Tetap Menurut Para Ahli. https://sarjanaekonomi.co.id/pengertian-aktiva-tetap-menurut-para-ahli/.

Ikatan Akuntan Indonesia. (2014). Pernyataan Standar Akuntansi Keuangan (PSAK) No 1: Penyajian Laporan Keuangan. Dewan Standar Akuntansi Indonesia Ikatan Akuntan Indonesia.

Ikatan Akuntan Indonesia. (2014). Pernyataan Standar Akuntansi Keuangan (PSAK) No 30: Sewa. Dewan Standar Akuntansi Indonesia Ikatan Akuntan Indonesia.

Ikatan Akuntan Indonesia. (2017). Draft Eksposur Pernyataan Standar Akuntansi Keuangan (PSAK) No.74: Sewa. Dewan Standar Akuntansi Indonesia Ikatan Akuntan Indonesia.

Ilmudes. (2015). 5 Alat Analisis Laporan Keuangan. https://www.ilmudes.com/2015/09/5-alatanalisis-laporan-keuangan.html

Kieso, Donald E., Jerry J. Weygandt, dan Terry D. Warfield. (2008). Intermediate Accounting IFRS Edition. Edisi Ke-3. WileyHarnas.

Martani, Dwi. (2019). Sewa PSAK 73. https://staff.blog.ui.ac.id/martani/2019/03/14/sewapsak-73.

Martono. (2002). Bank dan Lembaga Keuangan. Ekonisia.

Prajanto, Agung. (2020). Implementasi PSAK 73 atas Sewa Terhadap Kinerja Keuangan pada BUMN yang Terdaftar di Bursa Efek Indonesia. Jurnal Akuntansi, Keuangan, dan Auditing, No. 2 (Vol 1), 2020, Hal: 01-08.

Putri, Rizky Ananda. (2020). Analisis Perbandingan Dampak Pengakuan dan Pengukuran Sewa oleh Penyewa Berdasarkan PSAK 30 dan PSAK 73 terhadap Pelaporan Sewa dan Kinerja Keuangan PT Telekomunikasi Indonesi (Persero) Tbk [Skripsi]. Universitas Brawijaya.

Safitri, Amelia, Utami P. Lestari, Ida Nurhayati. (2019). Analsis Dampak Penerapan PSAK 73 atas Sewa Terhadap Kinerja Keuangan pada Industri Manufaktur, Pertambangan dan 


\section{JURNALKU}

Volume 1 No. 1, Maret 2021

Jasa yang Terdaftar di Bursa Efek Indonesia Tahun 2018. Prosding Industrial Research Workshop and National Seminar, 10 (01): 955-964.

Selly, N.Z. (2015). Pengertian, Penggolongan dan Perolehan Aset Tetap. http://repository.uma.ac.id/bitstream/123456789/781/5/138330034_file5.pdf.

Subramanyam, K.R. (2014). Financial statement analysis elevent edition. McGraw-Hill Education.

Sudjana, Michael Agyarana Barus Nengah. (2017). Penggunaan Rasio Keuangan untuk Mengukur Kinerja Keuangan Perusahaan [Skripsi]. Universitas Brawijaya.

Titman, Sheridan, Arthur J. Keown, John D. Martin. (2018). Financial management principles and applications thirteenth edition. Pearson Education Limited.

Tom, Mc Ifle. (2016). Mengapa Analisis Keuangan Sangat Penting. https://www.tommcifle.com/mengapa-analisis-keuangan-sangat-penting/.

Wardhani, HK. (2020). Analisis Implementasi PSAK 73 Terhadap Perlakuan Akuntansi Sewa Guna Usaha (Leasing) PT PLN Unit Induk Distribusi Jawa Timur [Tugas Akhir]. Universitas Airlangga. 